\title{
1 Chemical communication in springtails: a review of facts and perspectives
}

2 Sandrine Salmon ${ }^{1}$, Sylvie Rebuffat ${ }^{2}$, Soizic Prado $^{2}$, Michel Sablier ${ }^{3}$, Cyrille D’Haese ${ }^{1}$, Jian-Sheng

3 Sun $^{4}$, Jean-François Ponge ${ }^{1}$

$4{ }^{1}$ Muséum National d'Histoire Naturelle, Département Adaptations du Vivant, UMR 7179 MECADEV, 54 avenue du Petit Château, 91800 Brunoy, France

${ }^{2}$ Muséum National d'Histoire Naturelle, Département Adaptations du Vivant, UMR 7245 MCAM, 57 rue Cuvier, CP 54, 75005 Paris, France

8

9

${ }^{3}$ Muséum National d'Histoire Naturelle, Département Origines et Évolution, USR 3224 CRC, 57 rue Cuvier, CP 21, 75005 Paris, France

${ }^{4}$ Muséum National d'Histoire Naturelle, Département Adaptations du Vivant, 57 rue Cuvier, CP 26, 75005 Paris, France

Corresponding author: Jean-François Ponge, ponge@mnhn.fr, tel. +33 678930133

ORCID numbers: Sandrine Salmon: 0000-0003-1873-6940, Sylvie Rebuffat: 0000-0002-5257-5039, Soizic Prado: 0000-0002-8071-9642, Michel Sablier: 0000-0001-6508-8566, Cyrille D’Haese: 00000001-6065-0927, Jian-Sheng Sun: 0000-0003-0614-1931, Jean-François Ponge: 0000-0001-65045267

\section{Abstract}

The present knowledge on chemical communication in springtails (Collembola), one of the two most abundant invertebrate groups living in soil and environments in tight contact with soil (e.g. plant litter, moss), is reviewed here. Chemical communication in an environment where light is absent or dimmed becomes a prominent driver of trophic and non-trophic interactions between soil organisms at a time when better knowledge on the biological determinants of soil communities is required. Like insects and many other arthropods, collembolan individuals of the same population intercommunicate by 
24 pheromones, which allow them to signal a risk or to cluster in places favourable for feeding, mating, 25 moulting and ovipositing. Olfaction is also used to select preferred food and mates. Researches so far 26 conducted allowed to discern common trends in the role and chemical composition of odour blends

27 used by Collembola. However, much more needs to be done before reaching straightforward

28 conclusions about chemical communication issues at evolutionary and community levels, making this 29 domain even more rewarding.

30 Keywords: Chemical communication, Collembola, Pheromones, Aggregation, Phylogeny, 31 Community 


\section{Introduction}

Chemical communication among soil organisms is a still poorly explored scientific domain, despite recent focus on the functional importance of chemical signalling in plant-microbial (Peters and Verma 1990; Sanon et al. 2009; Combès et al. 2012), plant-faunal (Blouin et al. 2005; Rosenstiel et al. 2012; Leach et al. 2017) and plant-faunal-microbial interactions (Bonkowski 2004; Bais et al. 2006; Jousset et al. 2008). However, better knowledge of these interactions might illuminate our still imperfect knowledge of soil food webs (DeAngelis 2016). Ignored for a long time, positive interactions (Bertness and Callaway 1994; Leigh and Rowell 1995; Stachowicz 2001) are now recognized as a key process in the building and stability of communities, involving plants, microbes and animals (Wall and Moore 1999; Callaway et al. 2002; Wisz et al. 2013). Positive interactions are also acknowledged as a driving force of evolution (Laland and Boogert 2010; Rosenberg and Zilber-Rosenberg 2016; Prinzing et al. 2017). Negative and positive interactions among species are at least partly governed by chemical signals (Callaway 2002; Taga and Bassler 2003). This makes chemical communication a key factor of species coexistence (Vet 1999; Austin et al. 2014).

Chemical signals, based on volatile (olfactory) or contact molecules (O’Connell 1986), are known to play a prominent role in positive as well as negative interactions between soil organisms (Wenke et al. 2010; Lavelle et al. 2016). In soil invertebrates, they play a direct role in mating (Zizzari et al. 2017), search for food (Brückner et al. 2018), search of safe sites for growth and reproduction (Kuenen and Nooteboom 1963), aggregation (Benoit et al. 2009), avoidance of death risk (Nilsson and Bengtsson 2004a), prey location and catching (Huber 1978) and deterrence of predators (Smolanoff et al. 1975). Some chemical compounds excreted by soil animals have hormonal properties which stimulate the growth of plants and their resistance against stress factors and pathogens (Puga-Freitas and Blouin 2015). All these chemical signals are known as semiochemicals and are classified into two broad classes depending on their intra- or interspecific action. Pheromones are intraspecific compounds capable of acting outside the body of the secreting individual to impact the behaviour of a receiving individual of the same species (Karlson and Lüscher 1959). These chemical signals allow 
individuals of the same species to interact between them in the course of aggregation (aggregation pheromones), mating (sex pheromones) or by signalling a risk (alarm pheromones) (Wilson and Bossert 1963; Shorey 1973). Conversely, allelochemicals are interspecific molecules that are grouped according to the benefits they provide to both producer and receiver. Allomones, kairomones and synomones are produced by a given species and act on another species (Sbarbati and Osculati 2006). They are favourable either to the producer (allomones, e.g. repulsive odours) or to the receiver (kairomones, e.g. fungal odours), or to both of them (synomones).

Springtails (Collembola) are among the most widespread and abundant groups of soil arthropods (20,000 to 400,000 individuals.m²), and as such they impact ecosystem functioning (Seastedt 1984; Hopkin 1997). They have long been considered as insects, but now belong to a separate taxonomic class. Collembola are phylogenetically sisters of other hexapods, which comprise mainly the insects. They are divided into four orders: Entomobryomorpha ( 4000 known species), Poduromorpha ( $\sim 3300$ species), Symphypleona ( 1200 species) and Neelipleona ( $\sim 50$ species). These microarthropods ( $0.25-3 \mathrm{~mm}$ in length) live mainly, but not exclusively, in soil and litter. The main role of Collembola is the decomposition of organic matter and the recycling of nutrients that can subsequently be taken up by plants (De Vries et al. 2013). They exert a direct action on organic matter decomposition and recycling of nutrients through the consumption of litter. Indirect effects occur through the regulation and dispersion of microorganisms (fungi and bacteria on which they feed), which are responsible for the mineralization of organic matter. As the role of Collembola varies according to species, the chemical communication regulating the interactions between Collembola species indirectly impacts soil functioning (Bardgett and Van der Putten 2014).

Collembola are known for a long time for their aggregative behaviour (Glasgow 1939). Aggregation is mediated by environmental heterogeneity (Poole 1961; Usher 1969), mass dispersal (Lyford 1975), selection of proper habitats (Joosse 1970; Verhoef and Nagelkerke 1977; Salmon and Ponge 1999; Auclerc et al. 2009) and food resources (Ponge 2000; Salmon 2004; Chauvat et al. 2014). Evidence for the existence of sex (Waldorf 1974a) and aggregation pheromones (Mertens and 
Bourgoignie 1977; Verhoef et al. 1977a, b) stimulated studies on olfactory signals involved in communication between congeners and mates in an environment and a zoological group such as soildwelling species where visual systems are rudimentary (Leinaas 1983; Pfander and Zettel 2004; Porco et al. 2009). Remarkable fossils preserved in Early Cretaceous amber allow describing a courtship behaviour in a Symphypleona and an aggregative behaviour in an Entomobryomorpha, thus suggesting the presence of pheromones more than 105 Ma ago (Sánchez-García et al. 2018). However, information on the importance of chemical communication for coexistence or avoidance and the evolution of collembolan species is still scarce (Nilsson and Bengtsson 2004b, Wertheim et al. 2005).

Given the accumulated data it is now time to review the present state of knowledge on chemical communication in Collembola, and make a prospect of ecological and evolutionary perspectives.

\section{The use of pheromones, allomones and kairomones by Collembola}

Collembola are endowed with a strong sensitivity to olfactory signals. Receptors are mostly localized on the antenna, in particular the two apical segments. This has been demonstrated directly by anatomical investigations (Keil 1999; Kollmann et al. 2011), total and partial antennal amputations (Waldorf 1976; Verhoef et al. 1977b), and indirectly by checking antennal cleaning behaviour (Waldorf 1974b). However, the chemosensitivity of other cephalic organs like postantennal organs cannot be excluded (Karuhize 1971; Altner and Thies 1976). Although this has not been demonstrated as yet on these tiny arthropods, it can be postulated that the double nature of the antennae allows them not only to detect chemical signals at distance, but also to evaluate the direction of the odour source like in insects (Bell and Tobin 1982). This might explain directional movements towards preferred food (Auclerc et al. 2010), as it has been observed in aboveground invertebrates (Schooley and Wiens 2003). Furthermore, pheromones produced by collembolans can also be diverted from their purpose and used as kairomones by predators to detect their prey (Kielty et al. 1996).

\section{Aggregation pheromones}


110 Pheromones play a key role in the aggregation process of Collembola, such as in numerous other

111 arthropods (Ishii and Kuwahara 1967; Wertheim et al. 2005). They have been first evidenced by their

112 effects, e.g. the fact that a place previously conditioned by the presence of one or more individuals

113 becomes attractive to conspecifics (Mertens and Bourgoignie 1977; Verhoef et al. 1977a, b; Mertens et

114 al. 1979; Joosse and Koelman 1979). When extracted from a conditioned substrate with an appropriate

115 solvent, pheromones were able to reproduce the same phenomenon (Manica et al. 2001). However,

116 these experiments did not demonstrate that the molecules were remotely detected. In fact, erratic

117 movements of an animal may favour random encounters with conditioned places, upon which the

118 animal ceases to move: only contact (non-volatile) molecules are required in this type of chemical

119 signalling. Other experiments showed that individuals attracted and induced the aggregation of

120 conspecifics without any contact or visual signal, suggesting a volatile signal (Leonard and Bradbury

121 1984; Krool and Bauer 1987). Motility decreased then ceased totally at high concentration, i.e. at short

122 distance from conspecifics (Shorey 1973; Mertens and Bourgoignie 1977).

Aggregation pheromones have been evidenced in a large number of collembolan species

(Table 1), encompassing Poduromorpha and Entomobryomorpha living above or below ground in various environments. Surprisingly, Neelipleona and Symphypleona are absent from this list, when excluding short courtships displayed between sexual partners (Betsch-Pinot 1977; Kozlowski and Shi 2006).

Aggregation pheromones allow encounters between individuals of the same species in places favourable for feeding (Barra and Christiansen 1975; Benoit et al. 2009), mating (Joosse 1970; Verhoef and Nagelkerke 1977), moulting (Joosse and Verhoef 1974; Verhoef and Nagelkerke 1977) and ovipositing (Verhoef and Nagelkerke 1977; Benoit et al. 2009). Aggregation in favourable microniches is of paramount importance to limit water losses (Joosse 1970; Benoit et al. 2009). Limiting water loss is more particularly required during moulting periods which happen repetitively all along the life of Collembola (Verhoef and Nagelkerke 1977). Synchronized moulting controlled by chemical communication has been demonstrated in group-living hypogastrurids (Leinaas 1983). It also appears 
that species that are most sensitive to desiccation would be also most prone to aggregation (Joosse 1970, 1971). Awaiting further confirmation on a larger array of species, parthenogenetic species are less prone to aggregation than sexual species (Chernova et al. 2010). Although aggregations comprising different species are commonplace in Collembola (Poole 1961; Hale 1966; Benoit et al. 2009; Joosse 1970), only two cross-species attractions by pheromones have been demonstrated (Tomocerus minor attracted to Orchesella villosa and O. cincta) out of the three interactions tested in two independent studies (Verhoef et al. 1977a, Benoit et al. 2009).

Aggregation pheromones are produced by adults of both sexes (Verhoef et al. 1977a; Krool and Bauer 1987), even during starvation (Verhoef 1984) and moulting periods (Verhoef and Nagelkerke 1977; Verhoef et al. 1977a). Their production is negatively abundance-dependent (Verhoef 1984). They are deposited on the substrate (Mertens and Bourgoignie 1977) and some of them are seemingly volatile, being attractive at distance (Verhoef et al. 1977a; Leonard and Bradbury 1984; Krool and Bauer 1987; Manica et al. 2001; Nilsson and Bengtsson 2004b). They are emitted through the intestine, as being found in the faeces (Verhoef 1984), but probably also through the cuticle, as they were detected in extracts from entire uncrushed individuals (Benoit et al. 2009).

\section{Sex pheromones}

Sex pheromones are produced by females, conditioning the deposition of spermatophores by males (Waldorf 1974a) and attracting them (Porco et al. 2009) while spermatophores produced by males are also known to attract females (Zizzari et al. 2017). They are present in the cuticle (Porco et al. 2004, 2009) and in spermatophores (Zizzari et al. 2017). Sex pheromones are thought to mediate sexual selection (Hedlund et al. 1990; Stam et al. 2002; Zizzari et al. 2009). Although still largely speculative in the studied group, the idea of an evolutionary role of sex pheromones has been considered by entomologists (Greenfield 1981; Symonds and Elgar 2008), but deeper research in this direction is needed before clear hypotheses could emerge.

\section{Alarm pheromones and allomones}


Alarm pheromones have been recorded in a number of species, belonging to Poduromorpha, Entomobryomorpha and Symphypleona (Table 2). They are emitted after rupture of the cuticle when springtails die (necromones), or in the presence of predators. They elicit a dispersive behaviour of conspecifics (Purrington et al. 1991; Nilsson and Bengtsson 2004a). Defence strategies vary according to the taxonomic group considered. Some collembolan species have an aggregative behaviour in the presence of a predator, while others move away from each other. This suggests various behavioural effects of alarm pheromones (Negri 2004).

Predator-repulsive allomones have been shown to be emitted by podurid species, e.g. Ceratophysella denticulata against a rove beetle (Bitzer et al. 2004), or the giant springtail Tetradotonphora bielanensis against a ground beetle (Dettner et al. 1996). The emission of predatorrepulsive allomones occurs when predatory attack is simulated with a needle as in Protaphorura lata (Usher and Balogun 1966). However, the odour of springtails may also be used by some of their predators as a cue to catch them, such as in the ground beetle Nebria brevicollis (Kielty et al. 1996).

\section{Kairomones}

Preferences for some food items are known for a long time (Knight and Angel 1967). Despite a wide array of food items potentially used by the same species, preferences may differ to a large extent among species (Jørgensen et al. 2005; Ferlian et al. 2015). It has been shown that selection of or attraction to preferred food can be mediated by olfaction. Indeed, it occurs in advance, and even in the absence of tasting (Salmon and Ponge 2001; Staaden et al. 2011; Chauvat et al. 2014). Attraction to preferred food is associated with directional and rapid movements towards the odour source upon detection at a distance varying from 1 to 40 cm (Bengtsson et al. 1994; Salmon and Ponge 2001; Auclerc et al. 2010). Attraction is followed by cessation of movement in the presence of food (Westerberg et al. 2008).

Microcosm experiments demonstrated that fungal strains are preferred or avoided when their odour is attractive or repellent, respectively (Bengtsson et al. 1988; Hedlund et al. 1995; SadakaLaulan et al. 1998). They also demonstrated that discrimination between preferred and discarded 
fungal colonies is mediated by secondary metabolites (Staaden et al. 2011). Preferred fungal strains maximize fitness parameters, with the exception of a few erroneous choices (Sadaka-Laulan et al. 1998; Heděnec et al. 2013). The volatile compounds present in the odour of preferred fungal strains were isolated and tested. An attractive effect of some specific compounds was demonstrated on the onychiurid Protaphorura armata (Bengtsson et al. 1991). A strong influence of fungal defence chemicals on the aggregative behaviour of the fungus-feeding Folsomia candida has also been shown by using wild-type fungi and modified strains lacking the ability to secrete secondary metabolites (Stötefeld et al. 2012).

Collembolan olfactory cues are also provided by mosses. A win-win process is mediated by moss volatile compounds which act as kairomones. They increase moss fertilization success by favouring collembolan search for preferred habitat (Gerson 1969) and even for preferred food, although it has not been proven that sperm cells can act as a reward (Rosenstiel et al. 2012). Kairomones are also emitted by leaf litter, repellence to the collembolan Sinella coeca being induced by isoprene (2-methylbuta-1,3-diene) (Michelozzi et al. 1997). Repellence mediated by the smell of artificial compounds, such as the herbicide 2,4,5-T (2,4,5-trichlorophenoxyacetic acid), has also been demonstrated in Onychiurus quadriocellatus (Eijsackers 1978). The odour of soil animals, e.g. earthworm themselves and their excreta, can be perceived at distance and used as a cue to find proper food and habitat, including protection from predators (Salmon and Ponge 2001; Salmon 2001, 2004; Salmon et al. 2005).

All these results point to a fundamental role of chemical communication in the functional relationships between soil organisms (DeAngelis 2016) and co-adaptation experiments even suggest that they could play a key role in the co-evolution between insects and fungi (Biedermann et al. 2019). It is here suggested that attractive, neutral and repellent odours could explain the so-called 'home-field advantage hypothesis', i.e. the optimization of litter decomposition when decomposers are processing litter in their own habitat (Perez et al. 2013; Austin et al. 2014; Veen et al. 2015). They could also explain 'natal habitat preference induction', i.e. the propensity of animal species to disperse in an environment that contains stimuli similar to those found in their original environment (Stamps and 


\section{Composition of collembolan semiochemicals}

Most insect pheromones are made of mixtures of various molecules, the proportion of which varies among species and within and among populations of the same species (Wertheim et al. 2005; Symonds and Elgar 2008). In various species, aggregation and sex pheromones are alcohols, esters, amino acids, fatty acids, aldehydes and ketones commonly linked to a hydrophobic alkyl chain. They are often derived from fatty acids, or from phenol (O’Connell 1986; Leal 1997; Tillman et al. 1999). Recognition mechanisms based on insect pheromones are highly species-specific (Roelofs and Brown 1982; De Bruyne and Baker 2008; Kaissling 2014). This suggests that in collembolan too, the ratio of chemical compounds found in pheromones allows a fine tuning between emitters and receptors (Bruce et al. 2005; Lei et al. 2013).

In Collembola, various compounds have been isolated among alarm pheromones and necromones (chemicals arising from dead individuals). Most of them are aromatic compounds and fatty acids (Purrington et al. 1991; Messer et al. 1999; Nilsson and Bengtsson 2004b). Some compounds commonly isolated from collembolan alarm pheromones, such as linoleic acid, have a wide spectrum of action, being accordingly repulsive to ants, aphids, beetles and woodlice (Greenway et al. 1978; Nijholt 1980; Howard and Blomquist 1982; Rollo et al. 1994). Three compounds have been isolated from collembolan repulsive allomones (Table 3). The onychiurids T. bielanensis, Deuteraphorura scotaria and Onychiurus circulans were shown to excrete 2,3-dimethoxy-pyrido[2,3b] pyrazine, a heterocyclic aromatic compound. However, the repellent effect of this molecule has only been observed in T. bielanensis. Furthermore, all onychiurids do not produce this molecule, since it has not been found in P. armata (Dettner et al. 1996; Nilsson and Bengtsson 2004b). These compounds were identified in fluids excreted by secretory organs (pseudocella) and were not found in food and faeces (Dettner et al. 1996). The hypogastrurid Ceratophysella denticulata was shown to excrete 3-hydroxy-4,5-dimethoxybenzoic acid (DmHbA) and 4-hydroxy-3,5-dimethoxybenzoic acid, better known as syringic acid (Bitzer et al. 2004). These phenolic acids are known for their strongly 
irritating properties (Hayashi et al. 1999). The strong resemblance between repellent substances

emitted by arthropods and allelochemicals produced by plants against herbivores (and other plants, i.e. allelopathy) has been highlighted a long time ago (Smolanoff et al. 1975). It can be explained by the use of plant semiochemicals as precursors of insect pheromones (Reddy and Guerrero 2004; Stökl and Steiger 2017; Blomquist et al. 2010). Nevertheless, Malcicka et al. $(2017,2018)$ showed that, similar to some other soil invertebrates, some collembolan species were able to synthesize de novo linoleic acid, a common component of alarm pheromones, while other arthropods needed to get it from their food. The attraction of males of $T$. bielanensis by the odour of females was shown to be mediated by the polar fraction of cuticular extracts, e.g. fatty acids, ketones, alcohols and esters (Porco et al. 2009). The (Z)-14-tricosenol hydrocarbon was shown to be the main volatile compound emitted by spermatophores (spermatic capsules deposited on the substrate) of the entomobryid Orchesella cincta (Zizzari et al. 2017). We did not find any study describing unambiguously the identification and biological activity of aggregation pheromones isolated from collembolan extracts. The only exception is a recent study in which potentially attractive cuticular extracts were isolated and fatty acids proposed as the pheromones (Liu and Wu 2017). However, the authors neither demonstrated unambiguously the role of the extracts in aggregation nor the emission or excretion of the compounds in the environment. Hence in the conducted experiments, the extracted fatty acids could have been dissolved from the animal body (Malcicka et al. 2017), making the results questionable. In the search of necromones (repellent molecules), synthetic palmitic acid was shown to be attractive to $P$. armata and was present in P. armata, Folsomia candida, D. scotaria and O. circulans (Nilsson and Bengtsson 2004a, b). However, these authors could not demonstrate that $P$. armata was attractive to $O$. circulans and $D$. scotaria. It suggests that the sensitivity to a given concentration of palmitic acid can vary according to species. Furthermore, fatty acids and fatty acid-related compounds (e.g. n-alkanes, nalcohols) are well-known as persistent components of soil organic matter (Marseille et al. 1999). Consequently, distinguishing their potential role in aggregation phenomena is very challenging (Baldock and Nelson 2000, Reiffarth et al. 2016). 
Despite their lack of chemical identification, diverse solubility and polarity properties of some

collembolan aggregation pheromones have been established as yet. Those produced by Hypogastrura viatica and $O$. cincta (Mertens et al. 1979) are soluble in water while those emitted by the semiaquatic Anurida maritima are insoluble in water but soluble in methanol (Manica et al. 2001). Aggregation pheromones extracted from Cryptopygus antarcticus and Friesea grisea were more soluble in methanol than in water and acetone, and were insoluble in hexane (Benoit et al. 2009). Those extracted from P. armata and F. candida were soluble in cyclohexane, hexane or dichloromethane (Nilsson and Bengtsson 2004a; Liu and Wu 2017). This wide range of polarities, while pointing to a common poor solubility in water, highlights the diversity of chemical compounds that can play a role as aggregation pheromones among collembolan species, as well as the difficulty to establish an efficient and common protocol for their isolation. The chemical characterization of such pheromones is still also challenging, most probably because there are produced at very low concentration. This implies a high number of individuals necessary for pheromone collection (Benoit et al. 2009). Olfactory attraction tests allowed deducing that aggregation pheromones are at least composed of some volatile molecules, while the effect of non-volatile molecules acting by contact cannot be excluded (Benoit et al. 2009). Given our knowledge of the chemical compositions of insect pheromones, it can be reasonably hypothesized that collembolan pheromones should be also complex mixtures of a broad range of chemical compounds (Wertheim et al. 2005).

\section{Ecological and evolutionary perspectives in chemical communication}

\section{among Collembola}

Given that our knowledge on chemical communication among arthropods is mainly based on insect pheromones, we will present some 'insect' facts which should be of interest for future studies of Collembola semiochemicals. Among the most attractive research directions we can identify (i) the evolutionary point of view, and (ii) the roles played by the microbiota associated with springtails. The metabolic potential of endo- and ectomicrobiota opens new tracks. Furthermore, some of the molecules previously identified as springtail pheromones may possibly originate from the 
microorganisms they host.

First, we question at which phylogenetic level olfactory signals vary, and whether they intervene in speciation mechanisms. It is known that scarab beetles of the same genus share the same sex pheromones (Leal 1997). This suggests that in this zoological group, speciation was allopatric and mediated by natural geographic or temporal discontinuities. Inter-species pheromone interactions even occur between species belonging to distinct insect orders, e.g. male wine flies responding to honey bee queen sex pheromones (Croft et al. 2017). In butterflies there were strong discrepancies between phylogenies based on morphological characters and those based on synthetic pathways of sex pheromones (Dugdale 1997). Most of these data nevertheless suggest a strong phylogenetic conservatism of sexual olfactory signals, as otherwise demonstrated in insect-plant interactions (Futuyma and Mitter 1996).

Contrary to sex pheromones, variegated results were obtained with insect aggregation pheromones. Despite preferences for conspecifics, cross-attraction between species belonging to various families is known as an adaptive mechanism thought to enhance species coexistence (Vet 1999; Wertheim et al. 2005). Working with phylogenetic distances, Symonds and Elgar (2004) showed that no links between morphologically- and chemically-based scolytid phylogenies could be evidenced. On the contrary, a close relationship between both phylogenies was shown in drosophilids (Symonds and Wertheim 2005). In the former case, random saltational shifts in chemical communication systems, a typical case of punctuated equilibrium (Gould and Eldredge 1993), are expected to favour sympatric speciation. In this case, like geographical or ecological isolation, aggregation pheromones create behavioural barriers against gene flow (Baker 2002; Wertheim et al. 2005; Mendelson et al. 2014). In the latter case, phyletic gradualism is expected because of the absence of selection pressure on aggregation pheromones, non-chemical cues being used in mate assortment (Symonds and Wertheim 2005).

Despite the lack of large datasets allowing discerning evolutionary trends in Collembola, some multi-species experiments deserve our attention. Positive as well as negative results of cross-repulsion 
by necromones of another species were obtained (Purrington et al. 1991; Nilsson and Bengtsson 2004b). These results are not in favour of the existence of a phylogenetic signal related to necromones. Thus, further research is needed on this question, especially on sex or aggregation pheromones, before drawing straightforward conclusions. Multi-species attraction experiments in the order Entomobryomorpha showed that Tomocerus minor (family Tomoceridae) was attracted by aggregation pheromones of two species of Orchesella (family Entomobryidae), while Orchesella species were only attracted by their conspecifics (Verhoef et al. 1977a). On the contrary, two co-occurring Antarctic species, Cryptopygus antarcticus (Entomobryomorpha, family Isotomidae) and Friesea grisea (Poduromorpha, family Neanuridae) did not reveal any cross-attraction (Benoit et al. 2009). The same was observed for $P$. armata versus $O$. circulans and $D$. scotaria, all belonging to the same Onychiuridae family in Poduromorpha (Nilsson and Bengtsson 2004b). To date, no research of crossattraction has been reported in Symphypleona and Neelipleona, the former displaying elaborate mating courtships in many species. Clearly, all these results are insufficient to discern a pattern of attraction as a function of the phylogenetic distance between species, since only one cross-attraction was observed between species belonging to different families. Consequently inferring a general trend in the role of chemical communication in collembolan species assembly rules and speciation is premature. Nevertheless, the partial results so far obtained point to the existence of asymmetrical effects of semiochemicals across species. Some species repel or attract other species, while the reverse does not apply (species “1” repels or attracts species “2”, but species “2” does not repel or attract species “1”). This might contribute to explain dominance effects in multi-species laboratory cultures (Christiansen 1967; Culver 1974; Christiansen et al. 1992; Walsh and Bolger 1993). Such mechanisms might also explain the field co-occurrence (Benoit et al. 2009) or on the contrary segregation (Ponge 1973; Ponge and Salmon 2013) of species sharing similar ecological requirements.

Some aspects of chemical communication, so far unquestioned within soil ecosystems, should now deserve the attention of researchers. When several species are attracted to the same food or habitat (Maraun et al. 2003; Staaden et al. 2011; Boulay et al. 2019), several events can occur following the encounter instar. Both species can compete by using the same resource (exploitative 
competition), or be expelled from each other (interference competition), or even one of them may kill the other (egg predation, cannibalism). The sign (negative, positive, or nil) of pheromone interactions between species might determine the fate of their encounters. Indifference, avoidance or attraction might possibly act in advance of any contact or agonistic behaviour. Such a phenomenon cannot be revealed in laboratory culture conditions where species are constrained to cohabit in a restricted space. Positive or nil chemical interactions (between-species attraction or indifference, respectively) will result in multi-species aggregations around the same food or habitat, in the former case with a stabilizing mechanism according to Barot and Gignoux (2004). Conversely, negative interactions, whether symmetrical or asymmetrical, will result in either niche shifts or checkerboard distributions, according to different or similar ecological species requirements, respectively. A better knowledge of chemical communication systems might thus contribute to explain fine-scale niche segregation (Anderson 1978; Zhao et al. 2013) and competition-mediated over-dispersion of functional traits (Widenfalk et al. 2016), as observed in soil samples, and then to finally resolve the famous "enigma of soil animal species diversity” (Anderson 1975; Maraun et al. 2003; Wehner et al. 2016).

Finally, the development of our knowledge on the roles played by symbiotic and more largely associated microorganisms in the biology, physiology and biochemistry of any organism, from plants to mammals, thanks to metagenomics and metabolomics methods, opens avenues for further research on springtail communication molecules. Furthermore, many of the molecules previously identified as springtail pheromones are possibly originating from the microorganisms they host, rather than from the springtails themselves.

Undoubtedly, the role of the Collembola-associated microbiota in intra- and interspecies communication should be a major research field in the next decade. Until now, this role has been scarcely explored in insect communication since the 1970's, and more actively since 2000 (Dillon and Charnley 2002; Sharon et al. 2013). Gut microbiota appears as the most important insect-associated microbial community, contributing to the production of sex or aggregation pheromones, or to the insect defence. As an example, the gut microbiota of the desert locust Schistocerca gregaria was 
shown to produce guaiacol and phenols having both antimicrobial and aggregation pheromone functions (Dillon and Charnley 2002). Molecular defence in insects through their associated microorganisms has been largely explored (for a review, see Van Arnam et al. 2018). On another side, chemical studies point to the production of pyrazines as common communication molecules in many organisms, including Collembola (Dettner et al. 1996; Nilsson and Bengtsson 2004b). This suggests the possible involvement of the microbial compartment in animal chemical communication because pyrazine molecules are synthesized by several bacterial species (Dickschat et al. 2005).

However, in springtails, these orientations are still nascent. Bahrndorff et al. (2018) described the composition of the microbial communities associated with Orchesella cincta (Entomobryidae). The results supported a functional role of the microbiota in the enzymatic digestion of food, in the metabolism of aromatic amino acids that act as growth factors, and in soil metabolism including decomposition processes and biodegradation. However, the search for a role in communication was not a focus of the study.

\section{Conclusions and future research needs}

This review shows that the existence of aggregation, alarm and sex pheromones is unquestionable and verified experimentally. However, the studies suffered from several difficulties in collecting enough material for the identification of the molecules eliciting a signal. The small size of these animals, and difficulties in rearing them, notably but not only for Symphypleona, may explain why collembolan communication science does not make progress as fast as for other insects. Nothing is known on the receptors involved although strong clues indicate that antennal organs would play a role (Kollmann et al. 2011). It appears highly probable that given their phylogenetic position at the base of Hexapoda (Giribet et al. 2004), Collembola would share with bristletails the absence of specialized olfactory receptors (Missbach et al. 2014) to the benefit of generalized ionotropic receptors. Indeed, basal hexapods are proposed to have ionotropic receptors in common with Crustacea (Corey et al. 2013). Studies on antennal transcriptomes might solve this question. 
The origin and kind of molecules involved in collembolan chemical communication needs more attention to the methods used to extract them and experimentally reconstruct the processes in play in aggregation, mating, foraging, and other behavioural responses. The origin of extracted molecules should be clearly determined. Especially, it is crucial to know whether they are excreted in the environment by the animal or not, and from which organ or compartment in the animal they arise. The role of extracted and identified molecules should be unambiguously demonstrated. A simple and instantaneous attraction does not mean that a given molecule enters mandatorily in the composition of aggregation pheromones. These molecules have also to induce a decrease in motility and a clustering of individuals in the course of time. As an example, fatty acids extracted from the body of Folsomia candida and attracting F. candida (Liu and Wu 2017) are known to attract also other microarthropods towards food sources such as bacteria (Brückner et al. 2018). Thus, all attractive molecules are not necessarily pheromone components. Rather than yes/no sensitivity to a single compound, there are clues in favour of the ability of Collembola to react quantitatively to chemical 'fingerprints', like this has been shown to occur in other arthropods (Barata et al. 2002).

We also opened avenues in the evolutionary and functional importance of collembolan chemical communication. More research on multi-species aggregation (versus segregation) might throw light on the reasons why so many species contribute to similar or complementary functions in the same soil sample (Bardgett 2002) while repeated sampling shows so much unexplained microscale variation (Ims et al. 2004). Moreover, the roles that the associated microbial communities could play in the production of collembolan semiochemicals may explain several discrepancies observed in the results acquired until now, such as variations in the chemical nature of the main pheromone components identified according to the location of collected individuals or their number (Benoit et al. 2009). It also appears that many of the results accumulated for the last 40 years would need being reexamined in the light of analysing the composition and metabolic potential of the endo- and global associated microbiota, using metagenomics and metabolomics. In this context it is clear that, taking into-account the current methodological advances in analytical chemistry, massively parallel sequencing technology (NGS) and the potential applications of signalling molecules in various 
423 domains and particularly in agricultural ecology to reduce pest incidence (Beck et al 2018),

424 deciphering springtail communication strategies offers an extraordinary opportunity for future

425 multidisciplinary research.

\section{$426 \quad$ References}

427 Altner H, Thies G (1976) The postantennal organ: a specialized unicellular sensory input to the 428 protocerebrum in apterygotan insects (Collembola). Cell Tissue Res 167:97-110

429

430

431

432

433

434

435

Anderson JM (1975) The enigma of soil animal species diversity. In Vanek J (Ed) Progress in soil zoology. Academia, Prague, pp 51-58

Anderson JM (1978) Competition between two unrelated species of soil Cryptostigmata (Acari) in experimental microcosms. J Anim Ecol 47:787-803

Auclerc A, Libourel PA, Salmon S, Bels V, Ponge JF (2010) Assessment of movement patterns in Folsomia candida (Hexapoda: Collembola) in the presence of food. Soil Biol Biochem 42:657-659

Auclerc A, Ponge JF, Barot S, Dubs F (2009) Experimental assessment of habitat preference and dispersal ability of soil springtails. Soil Biol Biochem 41:1596-1604

Austin AT, Vivanco L, González-Arzac A, Pérez LI (2014) There’s no place like home ? An exploration of the mechanisms behind plant litter-decomposer affinity in terrestrial ecosystems. New Phytol 204:307-314

Bais HP, Weir TL, Perry LG, Gilroy S, Vivanco JM (2006) The role of root exudates in rhizosphere interactions with plants and other organisms. Ann Rev Plant Biol 57:233-266

Baker TC (2002) Mechanism for saltational shifts in pheromone communication systems. Proc Natl Acad Sci USA 99:13368-13370

Baldock JA, Nelson PN (2000) Soil organic matter. In Sumner ME et al. (eds) Handbook of soil 
science. CRC Press, Boca Raton, pp B25-B84

Barata EN, Mustaparta H, Pickett JA, Wadhams LJ, Araujo J (2002) Encoding of host and non-host plant odours by receptor neurones in the eucalyptus woodborer, Phoracantha semipunctata (Coleoptera: Cerambycidae). J Comp Physiol A 188:121-133

Bahrndorff, S, De Jonge N, Hansen JK, Lauritzen JMS, Spanggaard LH, Sorensen MH, Yde M, Nielsen JL (2018) Diversity and metabolic potential of the microbiota associated with a soil arthropod. Sci Reports 8:2491

Bardgett RD (2002) Causes and consequences of biological diversity in soil. Zoology 105:367-374

Bardgett RD, Van der Putten WH (2014) Belowground biodiversity and ecosystem functioning. Nature 515:505-511

Barot, S, Gignoux J (2004) Mechanisms promoting plant coexistence: can all the proposed processes be reconciled? Oikos 106:185-192

Barra JA, Christiansen K (1975) Experimental study of aggregations during the development of Pseudosinella impediens (Collembola, Entomobryidae). Pedobiologia 15:343-347

Beck JJ, Alborn HT, Block AK, Christensen SA, Hunter CT, Rering CC, Seidl-Adams I, Stuhl CJ, Torto B, Tumlinson JH (2018) Interactions among plants, insects, and microbes: elucidation of inter-organismal chemical communications in agricultural ecology. J Agric Food Chem 66:6663-6674

Bell WJ, Tobin TR (1982) Chemo-orientation. Biol Rev Cambridge Phil Soc 57:219-260

Bengtsson G, Erlandsson A, Rundgren S (1988) Fungal odour attracts soil Collembola. Soil Biol Biochem 20:25-30

Bengtsson G, Hedlund K, Rundgren S (1991) Selective odor perception in the soil Collembola Onychiurus armatus. J Chem Ecol 17:2113-2125 
Bengtsson G, Hedlund K, Rundgren S (1994) Food- and density-dependent dispersal: evidence from a soil collembolan. J Anim Ecol 63:513-520

Benoit JB, Elnitsky MA, Schulte GG, Lee RE Jr, Denlinger D.L (2009) Antarctic collembolans use chemical signals to promote aggregation and egg laying. J Insect Behav 22:121-133

Bertness MD, Callaway R (1994) Positive interactions in communities. Trends Ecol Evol 9:191-193

Betsch-Pinot MC (1977) Les parades sexuelles primitives chez les Collemboles Symphypléones. Rev Ecol Biol Sol 14:15-19

Biedermann PHW, De Fine Licht HK, Rohlfs M (2019) Evolutionary chemo-ecology of insect-fungus interactions: still in its infancy but advancing. Fungal Ecol 38:1-6

Bitzer C, Brasse G, Dettner K, Schulz S (2004) Benzoic acid derivatives in a hypogastrurid collembolan: temperature-dependent formation and biological significance as deterrents. J Chem Ecol 30:1591-1602

Blomquist GJ, Figueroa-Teran R, Aw M, Song MM, Gorzalski A, Abbott NL, Chang E, Tittiger C (2010) Pheromone production in bark beetles. Insect Biochem Mol Biol 40:699-712

Blouin M, Zuily-Fodil Y, Pham-Thi AT, Laffray D, Reversat G, Pando A, Tondoh J, Lavelle P (2005) Belowground organism activities affect plant aboveground phenotype, inducing plant tolerance to parasites. Ecol Lett 8:202-208

Bonkowski M (2004) Protozoa and plant growth: the microbial loop in soil revisited. New Phytol $162: 617-631$

Boulay J, Aubernon C, Ruxton GD, Hédouin V, Deneubourg JL, Charabidzé V (2019) Mixed-species aggregations in arthropods. Insect Sci 26:2-19

Bruce TJA, Wadhams LJ, Woodcock CM (2005) Insect host location: a volatile situation. Trends Plant Sci 10:269-274 
Brückner A, Schuster R, Smit T, Pollierer MM, Schäffler I, Heethoff M (2018) Track the snaff: olfactory cues shape foraging behaviour of decomposing soil mites (Oribatida). Pedobiologia $66: 74-80$

Callaway RM (2002) The detection of neighbors by plants. Trends Ecol Evol 17:104-105

Callaway RM, Brooker RW, Choler P, Kikvidze Z, Lortie CJ, Michalet R, Paolini L, Pugnaire FI, Newingham B, Aschehoug ET, Armas C, Kikodze D, Cook BJ (2002) Positive interactions among alpine plants increase with stress. Nature 417:844-848

Chauvat M, Perez G, Ponge JF (2014) Foraging patterns of soil springtails are impacted by food resources. Appl Soil Ecol 82:72-77

Chernova NM, Potapov MB, Savenkova YY, Bokova AI (2010) Ecological significance of parthenogenesis in Collembola. Entomol Rev 90:23-38

Christiansen K (1967) Competition between collembolan species in culture jars. Rev Ecol Biol Sol $4: 439-462$

Christiansen K, Doyle M, Kahlert M, Gobaleza D (1992) Interspecific interactions between collembolan populations in culture. Pedobiologia 36:274-286

Combès A, Ndoye I, Bance C, Bruzaud J, Djediat C, Dupont J, Nay B, Prado S (2012) Chemical communication between the endophytic fungus Paraconiothyrium variabile and the phytopathogen Fusarium oxysporum. PLoS ONE 7:e47313

Corey EA, Bobkov Y, Ukhanov K, Ache BW (2013) Ionotropic crustacean olfactory receptors. PLoS ONE 8:e60551

Croft JR, Liu T, Camiletti AL, Simon AF, Thompson GJ (2017) Sexual response of male Drosophila to honey bee queen mandibular pheromone: implications for generic studies of social insects. $\mathrm{J}$ Comp Physiol A 203:143-149 
Culver D (1974) Competition between Collembola in a patchy environment. Rev Ecol Biol Sol $11: 533-540$

DeAngelis KM (2016) Chemical communication connects soil food webs. Soil Biol Biochem 102:4851

De Bruyn, M, Baker TC (2008) Odor detection in insects: volatile codes. J Chem Ecol 34:882-897

Dettner K, Scheuerlein A, Fabian P, Schulz S, Francke W (1996) Chemical defense of giant springtail Tetrodotonphora bielanensis (Waga) (Insecta: Collembola). J Chem Ecol 22:1051-1074

De Vries FT, Thébault E, Liiri M, Birkhofer K, Tsiafouli MA, Bjørnlund L, Bracht Jørgensen H, Brady MV, Christensen S, De Ruiter PC, D’Hertefeldt T, Frouz J, Hedlund K, Hemerik L, Hol WHG, Hotes S, Mortimer SR, Setälä H, Sgardelis SP, Uteseny K, Van der Putten WH, Wolters V, Bardgett RD (2013) Soil food web properties explain ecosystem services across European land use systems. Proc Natl Acad Sci USA 110:14296-14301

Dickschat JS, Reichenbach H, Wagner-Dobler I, Schulz S (2005) Novel pyrazines from the myxobacterium Chondromyces crocatus and marine bacteria. Eur J Org Chem 4141-4153

Dillon R, Charnley K (2002) Mutualism between the desert locust Schistocerca gregaria and its gut microbiota. Res Microbiol 153:503-509

Dugdale JS (1997) Pheromone and morphology-based phylogenies in New Zealand tortricid moths. In Carde RT, Minks AK (eds) Insect pheromone research: new directions. Chapman and Hall, London, pp 463-472

Eijsackers H (1978) Side effects of the herbicide 2,4,5-T affecting mobility and mortality of the springtail Onychiurus quadriocellatus Gisin (Collembola). Z Angew Entomol 86:349-372

Ferlian O, Klarner B, Langeneckert AE, Scheu S (2015) Trophic niche differentiation and utilisation of food resources in collembolans based on complementary analyses of fatty acids and stable isotopes. Soil Biol Biochem 82:28-35 
Futuyma DJ, Mitter C (1996) Insect-plant interactions: the evolution of component communities. Phil Trans R Soc London B 351:1361-1366

Gerson U (1969) Moss-arthropod associations. Bryologist 72:495-500

Giribet G, Edgecombe GD, Carpenter JM, D’Haese C, Wheeler WC (2004) Is Ellipura monophyletic? A combined analysis of basal hexapod relationships with emphasis on the origin of inscts. Organ Divers Evol 4: 319-340

Glasgow JP (1939) A population study of subterranean soil Collembola. J Anim Ecol 8:323-353

Gould SJ, Eldredge N (1993) Punctuated equilibrium comes of age. Nature 366:223-227

Greenfield MD (1981) Moth sex pheromones: an evolutionary perspective. Florida Entomol 64:4-17

Greenway AR, Griffiths DC, Lloyd SL (1978) Response of Myzus persicae to components of aphid extracts and to carboxylic acids. Entomol Exp Appl 24:369-374

Hale WG (1966) A population study of moorland Collembola. Pedobiologia 6:65-99

Hayashi M, Nakamura Y, Higashi K, Kato H, Kishida F, Kaneko H (1999) A quantitative structureactivity relationship study of the skin irritation potential of phenols. Toxicol Vitro 13:915-922

Heděnec P, Radochová P, Nováková A, Kaneda S, Frouz J (2013) Grazing preference and utilization of soil fungi by Folsomia candida (Isotomidae: Collembola). Eur J Soil Biol 55:66-70

Hedlund K, Bengtsson G, Rundgren S (1995) Fungal odour discrimination in two sympatric species of fungivorous collembolans. Funct Ecol 9:869-875

Hedlund K, Ek H, Gunnarsson T, Svegborn C (1990) Mate choice and male competition in Orchesella cincta (Collembola). Experientia 46:524-526

Hopkin SP (1997) Biology of the springtails (Insecta: Collembola). Oxford University Press, Oxford Howard RW, Blomquist GJ (1982) Chemical ecology and biochemistry of insect hydrocarbons. Ann 
Rev Entomol 27:149-172

562

563

564

565

566

567

568

569

570

571

572

573

574

575

576

577

578

579

580

581

582

583

Huber I (1978) Prey attraction and immobilization by allomone from nymphs of Womersia strandtmanni (Acarina: Trombiculidae). Acarologia 20:112-115

Ims RA, Leinaas HP, Coulson S (2004) Spatial and temporal variation in patch occupancy and population density in a model system of an arctic Collembola species assemblage. Oikos 105:89-100

Ishii S, Kuwahara Y (1967) An aggregation pheromone of the German cockroach Blatella germanica L. (Orthoptera: Blatellidae). I. Site of the pheromone production. Appl Entomol Zool 2:203217

Joosse ENG (1970) The formation and biological significance of aggregations in the distribution of Collembola. Netherl J Zool 20:299-314

Joosse ENG (1971) Ecological aspects of aggregation in Collembola. Rev Ecol Biol Sol 8:91-97

Joosse ENG, Koelman TACM (1979) Evidence for the presence of aggregation pheromones in Onychiurus armatus (Collembola), a pest insect in sugar beet. Entomol Exp Appl 26:197-201

Joosse ENG, Verhoef HA (1974) On the aggregational habits of surface dwelling Collembola. Pedobiologia 14:245-249

Jørgensen HB, Johansson T, Canbäck B, Hedlund K, Tunlid A (2005) Selective foraging of fungi by collembolans in soil. Biol Lett 1:243-246

Jousset A, Scheu S, Bonkowski M (2008) Secondary metabolite production facilitates establishment of rhizobacteria by reducing both protozoan predation and the competitive effects of indigenous bacteria. Functional Ecology 2008:714-719

Kaissling KE (2014) Pheromone reception in insects: the example of silk moths. In: Mucignat-Caretta C (ed.) Neurobiology of chemical communication. CRC Press, Boca Raton, FL, pp 99-146 
Karlson P, Luscher M (1959) Pheromones: new term for a class of biologically active substances. Nature 183:55-56

Karuhize GR (1971) The structure of the postantennal organ in Onychiurus sp. (Insecta: Collembola) and its connection to the central nervous system. Z Zellforsch Mikroskop Anatomie 118:263282

Keil TA (1999) Morphology and development of the peripheral olfactory organs. In: Hansson BS (ed), Insect olfaction. Springer Nature, Stuttgart, pp 5-47

Kielty JP, Allen-Williams LJ, Underwood N, Eastwood EA (1996) Behavioral responses of three species of ground beetle (Coleoptera: Carabidae) to olfactory cues associated with prey and habitat. J Insect Behav 9:237-250

Knight CB, Angel RA (1967) A preliminary study of the dietary requirements of Tomocerus (Collembola). Am Midl Nat 77:510-517

Kollmann M, Huetteroth W, Schachtner J (2011) Brain organization in Collembola (springtails). Arthropod Struct Develop 40:304-316

Kozlowski MW, Shi AX (2006) Ritual behaviors associated with spermatophore transfer in Deuterosminthurus bicinctus (Collembola: Bourletiellidae). J Ethol 24:103-109

Krool S, Bauer T (1987) Reproduction, development, pheromone secretion in Heteromurus nitidus Templeton 1835 (Collembola, Entomobryidae). Rev Ecol Biol Sol 24:187-195

Kuenen DJ, Nooteboom HP (1963) Olfactory orientation in some land-isopods (Oniscoidea, Crustacea). Entomol Exp Appl 6:133-142

Laland KN, Boogert NJ (2010) Niche construction, co-evolution and biodiversity. Ecol Econom 69:731-736

Lavelle P, Spain A, Blouin M, Brown G, Decaëns T, Grimaldi M, Jiménez JJ, McKey D, Mathieu J, 
607

608

609

610

611

612

613

614

615

616

617

618

619

620

621

622

623

624

625

626

627

628

629

Velasquez E, Zangerlé A (2016) Ecosystem engineers in a self-organized soil: a review of concepts and future research questions. Soil Sci 181:91-109

Leach JE, Triplett LR, Argueso CT, Trivedi P (2017) Communication in the phytobiome. Cell 169:587-596

Leal WS (1997) Evolution of sex pheromone communication in plant-feeding scarab beetles. In Carde RT, Minks AK (eds), Insect pheromone research: new directions. Chapman and Hall, London, pp 505-513

Lei H, Chiu HY, Hildebrand JG (2013) Responses of protocerebral neurons in Manduca sexta to sexpheromone mixtures. J Comp Physiol A 199:997-1014

Leigh EG Jr, Rowell TE (1995) The evolution of mutualism and other forms of harmony at various levels of biological organization. Ecologie 26:131-158

Leinaas HP (1983) Synchronized moulting controlled by communication in group-living Collembola. Science 219:193-195

Leonard MA, Bradbury PC (1984) Aggregative behaviour in Folsomia candida (Collembola: Isotomidae), with respect to previous conditioning. Pedobiologia 26:369-372

Liu J, Wu DH (2017) Chemical attraction of conspecifics in Folsomia candida (Collembola). J Insect Behav 30:331-341

Lyford WH (1975) Overland migration of Collembola (Hypogastrura nivicola Fith) colonies. Am Midl Nat 94:205-209

Malcicka M, Ruther J, Ellers J (2017) De novo synthesis of linoleic acid in multiple Collembola species. J Chem Ecol 43:911-919

Malcicka M, Visser B, Ellers J (2018) An evolutionary perspective on linoleic acid synthesis in animals. Evolutionary Biology 45, 15-26. 
Manica A, McMeechan FK, Foster W.A (2001) An aggregation pheromone in the intertidal collembolan Anurida maritima. Entomol Exp Appl 99:393-395

Maraun M, Martens H, Migge S, Theenhaus A, Scheu S (2003) Adding to the 'enigma of soil animal diversity’: fungal feeders and saprophagous soil invertebrates prefer similar food substrates. Eur J Soil Biol 39:85-95

Marseille F, Disnar JR, Guillet B, Noack Y (1999) n-Alkanes and free fatty acids in humus and A1 horizons of soils under beech, spruce and grass in the Massif-Central (Mont-Lozère), France. Eur J Soil Sci 50:433-431

Mendelson TC, Martin MD, Flaxman S (2014) Mutation-order divergence by sexual selection: diversification of sexual signals in similar environments as a first step in speciation. Ecol Lett $17: 1053-1066$

Mertens J, Blancquaert JP, Bougoignie R (1979) Aggregation pheromone in Orchesella cincta (Collembola). Rev Ecol Biol Sol 16:441-447

Mertens J, Bourgoignie R (1977) Aggregation pheromone in Hypogastrura viatica (Collembola). Behav Ecol Sociobiol 2:41-48

Messer C, Dettner K, Schulz S, Francke W (1999) Phenolic compounds in Neanura muscorum (Collembola, Neanuridae) and the role of 1,3-dimethoxybenzene as an alarm substance. Pedobiologia 43:174-182

Michelozzi M, Raschi A, Tognetti R, Tosi L (1997) Eco-ethological analysis of the interaction between isoprene and the behaviour of Collembola. Pedobiologia 41:210-214

Missbach C, Dweck HKM, Vogel H, Vilcinskas A, Stensmyr MC, Hansson BS, Grosse-Wilde E (2014) Evolution of insect olfactory receptors. eLIFE 3:e02115

Negri I (2004) Spatial distribution of Collembola in presence and absence of a predator. Pedobiologia 48:585-588 
654

655

656

657

658

659

660

661

662

663

664

665

666

667

668

669

670

Nijholt WW (1980) Pine oil and oleic acid delay and reduce attacks on logs by ambrosia beetles (Coleoptera: Scolytidae). Can Entomol 112:199-204

Nilsson E, Bengtsson G (2004a) Death odour changes movement pattern of a Collembola. Oikos 104:509-517

Nilsson E, Bengtsson G (2004b) Endogenous free fatty acids repel and attract Collembola. J Chem Ecol 30:1431-1443

O’Connell RJ (1986) Chemical communication in invertebrates. Experientia 42:232-241

Perez G, Aubert M, Decaëns T, Trap J, Chauvat M (2013) Home-Field Advantage: a matter of interaction between litter biochemistry and decomposer biota. Soil Biol Biochem 67:245-254

Peters NK, Verma DPS (1990) Phenolic compounds as regulators of gene expression in plant-microbe interactions. Mol Plant-Microb Interact 3:4-8

Pfander I, Zettel J (2004) Chemical communication in Ceratophysella sigillata (Collembola: Hypogastruridae): intraspecific reaction to alarm substances. Pedobiologia 48:575-580

Ponge JF (1973) Application de l'analyse factorielle des correspondances à l'étude des variations annuelles dans les populations de microarthropodes. Bull Ecol 4:319-327

Ponge JF (2000) Vertical distribution of Collembola (Hexapoda) and their food resources in organic horizons of beech forests. Biol Fertil Soils 32:508-522

Ponge JF, Salmon S (2013) Spatial and taxonomic correlates of species and species trait assemblages in soil invertebrate communities. Pedobiologia 56:129-136

Poole TB (1961) An ecological study of the Collembola in a coniferous forest soil. Pedobiologia $1: 113-137$

Porco D, Deharveng L, Gers C (2004) Sexual discrimination with cuticular lipids in Schoetella ununguiculata (Tullberg, 1869) (Collembola: Hypogastruridae). Pedobiologia 48:581-583 
Porco D, Deharveng L, Skarżyński D (2009) Sex pheromone in Tetrodontophora bielanensis (Waga, 1842) (Collembola: Onychiuridae): indirect reproduction mediated by cuticular compounds. Pedobiologia 53:59-63

Prinzing A, Ozinga WA, Brändle M, Courty PE, Hennion F, Labandeira C, Parisod C, Pihain M, Bartish IV (2017) Benefits from living together? Clades whose species use similar habitats may persist as a result of eco-evolutionary feedbacks. New Phytol 213:66-82

Puga-Freitas R, Blouin M (2015) A review of the effects of soil organisms on plant hormone signalling pathways. Environ Exp Bot 114:104-116

Purrington FF, Kendall PA, Bater JE, Stinner BR (1991) Alarm pheromone in a gregarious poduromorph collembolan (Collembola: Hypogastruridae). Great Lakes Entomol 24:75-78

Reddy GVP, Guerrero A (2004) Interactions of insect pheromones and plant semiochemicals. Trends Plant Sci 9:253-261

Reiffarth EL, Petticrew PN, Owens DA Lobb DG (2016) Sources of variability in fatty acid (FA) biomarkers in the application of compound-specific stable isotopes (CSSIs) to soil and sediment fingerprinting and tracing: a review. Sci Total Environ 565:8-27

Roelofs WL, Brown RL (1982) Pheromones and evolutionary relationships of Tortricidae. Ann Rev Ecol Syst 13:395-422

Rollo CD, Czyzewska E, Borden JH (1994) Fatty acid necromones for cockroaches. Naturwissenschaften 81:409-410

Rosenberg E, Zilber-Rosenberg I (2016) Microbes drive evolution of animals and plants: the hologenome concept. mBio 7:e01395-15

Rosenstiel TN, Shortlidge EE, Melnychenko AN, Pankow JF, Eppley SM (2012) Sex-specific volatile compounds influence microarthropod-mediated fertilization of moss. Nature 489:431-433 
Sadaka-Laulan N, Ponge JF, Roquebert MF, Bury É, Boumezzough A (1998) Feeding preferences of the collembolan Onychiurus sinensis for fungi colonizing holm oak litter (Quercus rotundifolia Lam.). Eur J Soil Biol 34:179-188

Salmon S (2001) Earthworm excreta (mucus and urine) affect the distribution of springtails in forest soils. Biol Fertil Soils 34:304-310

Salmon S (2004) The impact of earthworms on the abundance of Collembola: improvement of food resources or of habitat? Biol Fertil Soils 40:323-333

Salmon S, Geoffroy JJ, Ponge JF (2005) Earthworms and Collembola relationships: effects of predatory centipedes and humus forms. Soil Biol Biochem 37:487-495

Salmon S, Ponge JF (1999) Distribution of Heteromurus nitidus (Hexapoda, Collembola) according to soil acidity: interactions with earthworms and predator pressure. Soil Biol Biochem 31:11611170

Salmon S, Ponge JF (2001) Earthworm excreta attract soil springtails: laboratory experiments on Heteromurus nitidus (Collembola: Entomobryidae). Soil Biol Biochem 33:1959-1969

Sánchez-García A, Peñalver E, Delclòs X, Engel MS (2018) Mating and aggregative behaviors among basal hexapods in the Early Cretaceous. PLoS One 13:e0191669

Sanon A, Andrianjaka ZN, Prin Y, Bally R, Thioulouse J, Comte G, Duponnois R (2009) Rhizosphere microbiota interfers with plant-plant interactions. Plant Soil 321:259-278

Sbarbati A, Osculati F (2006) Allelochemical communication in vertebrates: kairomones, allomones and synomones. Cells Tissues Organs 183:206-219

Schooley RL, Wiens JA (2003) Finding habitat patches and directional connectivity. Oikos 102:559570 
Rev Entomol 29:25-46

724

725

726

727

728

729

730

731

732

733

734

735

736

737

738

739

740

741

Sharon G, Segal D, Ringo JM, Hefetz A, Zilber-Rosenberg I, Rosenberg E (2013) Commensal bacteria play a role in mating preference of Drosophila melanogaster. Proc Natl Acad Sci USA 110:4853-4853

Shorey HH (1973) Behavioural responses to insect pheromones. Ann Rev Entomol 18:349-380

Smolanoff J, Kluge AF, Meinwald J, McPhail A, Miller RW, Hicks K, Eisner T (1975) Polyzonimine: a novel terpenoid insect repellent produced by a millipede. Science 188:734-736

Staaden S, Milcu A, Rohlfs M, Scheu S (2011) Olfactory cues associated with fungal grazing intensity and secondary metabolite pathway modulate Collembola foraging behaviour. Soil Biol Biochem 43:1411-1416

Stachowicz JJ (2001) Mutualism, facilitation, and the structure of ecological communities. BioScience $51: 235-246$

Stam E, Isaaks A, Ernsting G (2002) Distant lovers: spermatophore deposition and destruction behaviour by male springtails. J Insect Behav 15:253-268

Stamps JA, Swaisgood RR (2007) Someplace like home: experience, habitat selection and conservation biology. Appl Anim Behav Sci 102:392-409

Stökl J, Steiger S (2017) Evolutionary origin of insect pheromones. Curr Opinion Insect Sci 24:36-42

Stötefeld L, Scheu, S, Rohlfs M (2012) Fungal chemical defence alters density-dependent foraging behaviour and success in a fungivorous soil arthropod. Ecol Entomol 37:323-329

Symonds MRE, Elgar MA (2004) The mode of pheromone evolution: evidence from bark beetles. Proc R Soc London B 271:839-846

Symonds MRE, Elgar M.A (2008) The evolution of pheromone diversity. Trends Ecol Evol 23:220228 
Symonds MRE, Wertheim B (2005) The mode of evolution of aggregation pheromones in Drosophila species. J Evol Biol 18:1253-1263

Taga ME, Bassler BL (2003) Chemical communication among bacteria. Proc Natl Acad Sci USA 100:14549-14554

Tillman JA, Seybold SJ, Jurenka RA, Blomquist G.J (1999) Insect pheromones: an overview of biosynthesis and endocrine regulation. Insect Biochem Mol Biol 29:481-514

Usher MB (1969) Some properties of the aggregations of soil arthropods: Collembola. J Anim Ecol $38: 607-622$

Usher MB, Balogun RA (1966) A defence mechanism in Onychiurus (Collembola, Onychiuridae). Entomol Monthly Mag 102:237-238

Van Arnam EB, Currie CR, Clardy J (2018) Defense contracts: molecular protection in insect-microbe symbioses. Chem Soc Rev 47:1638-1651

Veen GF, Freschet GT, Ordonez A, Wardle DA (2015) Litter quality and environmental controls of home-field advantage effects on litter decomposition. Oikos 124:187-195

Verhoef HA (1984) Releaser and primer pheromones in Collembola. J Insect Physiol 30:665-670

Verhoef HA, Nagelkerke CJ (1977) Formation and ecological significance of aggregations of Collembola. Oecologia 31, 215-226.

Verhoef HA, Nagelkerke CJ, Joosse ENG (1977a) Aggregation pheromones in Collembola. J Insect Physiol 23:1009-1013

Verhoef HA, Nagelkerke CJ, Joosse ENG (1977b) Aggregation pheromones in Collembola (Apterygota): a biotic cause of aggregation. Rev Ecol Biol Sol 14:21-25

Vet LEM (1999) From chemical to population ecology: infochemical use in an evolutionary context. J Chem Ecol 25:31-49 
Waldorf ES (1974a) Sex pheromone in the springtail, Sinella curviseta. Environ Entomol 3:916-918

Waldorf ES (1974b) Variations in cleaning between the sexes of Sinella coeca (Collembola: Entomobryidae). Psyche 81:254-257

Waldorf ES (1976) Antennal amputation in Sinella curviseta (Collembola: Entomobryidae). Ann Entomol Soc Am 69:841-842

Wall DH, Moore J.C (1999) Interactions underground: soil biodiversity, mutualism, and ecosystem processes. BioScience 49:109-117

Walsh MI, Bolger T (1993) Effects of diet on the interactions between Hypogastrura denticulata Bagnall and Onychiurus furcifer Börner in laboratory cultures. Eur J Soil Biol 29:155-160

Wehner K, Norton RA, Blüthgen N, Heethoff M (2016) Specialization of Oribatid mites to forest microhabitats: the enigmatic role of litter. Ecosphere 7:e01336

Wenke K, Kai M, Piechulla B (2010) Belowground volatiles facilitate interactions between plant roots and soil organisms. Planta 231:499-506

Wertheim B, Van Baalen EJA, Dicke M, Vet LEM (2005) Pheromone-mediated aggregation in nonsocial arthropods: an evolutionary ecological perspective. Ann Rev Entomol 50:321-346

Westerberg L, Lindström T, Nilsson E, Wennergren U (2008) The effect on dispersal from complex correlations in small-scale movement. Ecol Modell 213:263-272

Widenfalk LA, Malmström A, Berg MP, Bengtsson J (2016) Small-scale Collembola community composition in a pine forest soil: overdispersion in functional traits indicates the importance of species interactions. Soil Biol Biochem 103:52-62

Wilson EO, Bossert WH (1963) Chemical communication among animals. Recent Prog Horm Res 19:673-716

Wisz MS, Pottier J, Kissling WD, Pellissier L, Lenoir J, Damgaard CF, Dormann, CF, Forchhammer 
MC, Grytnes JA, Guisan A et al. (2013) The role of biotic interactions in shaping distributions and realised assemblages of species: implications for species distribution modelling. Biol Rev $88: 15-30$

Zhao C, Griffin JN, Wu XW, Sun SC (2013) Predatory beetles facilitate plant growth by driving earthworms to lower soil layers. J Anim Ecol 82:749-758

Zizzari ZV, Braakhuis A, Van Straalen NM, Ellers J (2009) Female preference and fitness benefits of mate choice in a species with dissociated sperm transfer. Anim Behav 78:1261-1267

Zizzari ZV, Engl T, Lorenz S, Van Straalen NM, Ellers J, Groot AT (2017) Love at first sniff: a spermatophore-associated pheromone mediates partner attraction in a collembolan species. Anim Behav 124:221-227 
803 Table 1. Observations of aggregation pheromones in collembolan species.

\begin{tabular}{llll}
\hline Order & Superfamily & Species name & Literature source \\
\hline Poduromorpha & Hypogastruridae & Hypogastrura viatica & Mertens and Bourgoignie (1977) \\
Neanuridae & Anurida maritima & Manica et al. (2001) \\
Neanuridae & Friesea grisea & Benoit et al. (2009) \\
& Onychiuridae & Protaphorura armata & Joosse (1970), Joosse and Koelman (1979) \\
\hline Entomobryomorpha & Entomobryidae & Entomobrya nivalis & Joosse (1970) \\
& Entomobryidae & Heteromurus nitidus & Krool and Bauer (1987) \\
& Entomobryidae & Lepidocyrtus cyaneus & Joosse (1970) \\
& Entomobryidae & Orchesella cincta & Mertens and Bourgoignie (1977), Verhoef et al. (1977a) \\
& Entomobryidae & Orchesella villosa & Verhoef et al. (1977a) \\
& Tomoceridae & Tomocerus minor & Joosse (1970), Verhoef et al. (1977a) \\
& Isotomidae & Cryptopygus antarcticus & Benoit et al. (2009) \\
& Isotomidae & Folsomia candida & Leonard and Bradbury (1984) \\
& Isotomidae & Isotoma viridis & Joosse (1970) \\
& Isotomidae & Isotomurus palustris & Joosse (1970) \\
\hline
\end{tabular}


Table 2. Observations of alarm pheromones in collembolan species

\begin{tabular}{llll}
\hline Order & Superfamily & Species name & Literature source \\
\hline Poduromorpha & Hypogastruridae & Ceratophysella sigillata & Pfander and Zettel (2004) \\
& Hypogastruridae & Hypogastrura pannosa & Purrington et al. (1991) \\
& Neanuridae & Neanura muscorum & Messer et al. (1999), Purrington et al. (1991) \\
& Onychiuridae & Onychiurus encarpatus & Purrington et al. (1991) \\
& Onychiuridae & Protaphorura armata & Nilsson and Bengtsson (2004) \\
\hline Entomobryomorpha & Isotomidae & Folsomia candida & Purrington et al. (1991) \\
& Isotomidae & Isotomurus bimus & Purrington et al. (1991) \\
& Entomobryidae & Lepidocyrtus pallidus & Purrington et al. (1991) \\
\hline Symphypleona & Katiannidae & Sminthurinus elegans & Purrington et al. (1991) \\
\hline Neelipleona & Neelidae & Megalothorax minimus & Purrington et al. (1991) \\
\hline
\end{tabular}


Table 3. Communication molecules in springtails, localization and proposed functions

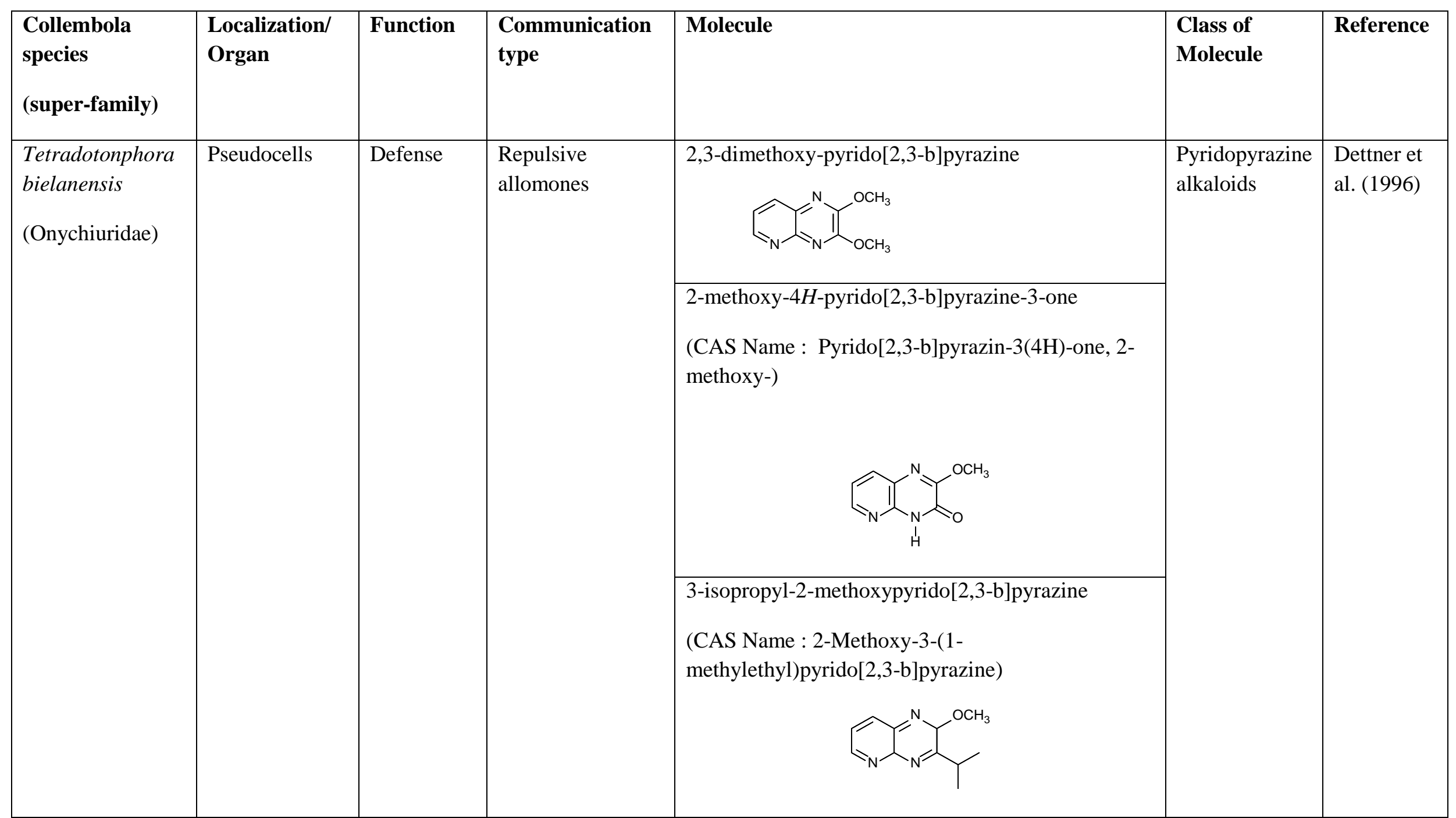




\begin{tabular}{|c|c|c|c|c|c|c|}
\hline $\begin{array}{l}\text { Protaphorura } \\
\text { armata } \\
\text { Deuteraphorura } \\
\text { scotaria } \\
\text { Onychiurus } \\
\text { circulans } \\
\text { (Onychiuridae) }\end{array}$ & $\begin{array}{l}\text { Unknown } \\
\text { (whole body } \\
\text { extract) }\end{array}$ & Defense & Necromone * & linoleic acid & Fatty acids & $\begin{array}{l}\text { Nilsson } \\
\text { and } \\
\text { Bengtsson } \\
\text { (2004b) }\end{array}$ \\
\hline
\end{tabular}




\begin{tabular}{|c|c|c|c|c|c|c|}
\hline (Neanuridae) & & & & $\mathrm{H}_{3} \mathrm{CO}$ & & \\
\hline $\begin{array}{l}\text { Orchesella cincta } \\
\text { (Entomobryidae) }\end{array}$ & $\begin{array}{l}\text { Male } \\
\text { spermatophores }\end{array}$ & \begin{tabular}{|l|} 
Female \\
attractant
\end{tabular} & Sex pheromone & (Z)-14-tricosenol & Polyene & $\begin{array}{l}\text { Zizzari et } \\
\text { al. (2017) }\end{array}$ \\
\hline $\begin{array}{l}\text { Protaphorura } \\
\text { armata } \\
\text { Onychiurus } \\
\text { scotarius } \\
\text { Onychiurus } \\
\text { circulans } \\
\text { (Onychiuridae) } \\
\text { Folsomia candida } \\
\text { (Isotomidae) }\end{array}$ & $\begin{array}{l}\text { Unknown } \\
\text { (whole body } \\
\text { extract) }\end{array}$ & $\begin{array}{l}\text { Conspecific } \\
\text { attractant }\end{array}$ & $\begin{array}{l}\text { Aggregation } \\
\text { pheromone* }\end{array}$ & palmitic acid & Fatty acid & $\begin{array}{l}\text { Nilsson } \\
\text { and } \\
\text { Bengtsson } \\
\text { (2004b) }\end{array}$ \\
\hline
\end{tabular}




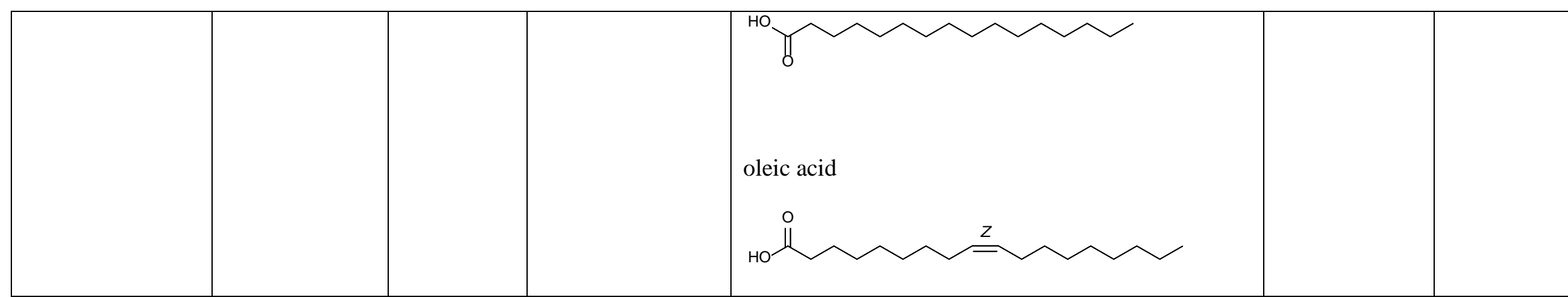

*Repellent and attractant effects of linoleic and palmitic acid, respectively have been demonstrated only against Protaphorura armata 